Digitalizacja archiwalnych numerów czasopisma naukowego Analecta Cracoviensia 1-24 (1969-1992)

i ich publikacja w otwartym dostępie - zadanie finansowane w ramach umowy 672/P-DUN/2017 ze środków

Ministra Nauki i Szkolnictwa Wyższego przeznaczonych na działalność upowszechniającą naukę

HERMANN J. POTTMEYER

\title{
TEOLOGIA FUNDAMENTALNA WOBEC NOWEGO WYZWANIA \\ Zewnętrzne i wewnętrzne uzasadnienie wiarogodności chrześcijaństwa
}

\author{
NOWE WYZWANIE
}

Do zadań teologii fundamentalnej należy argumentatywnie ukazywać wiarygodność chrześcijaństwa ${ }^{1}$. W dialogu $\mathrm{z}$ niewierzącymi argumentacja ta stanowi racjonalny dyskurs, w którym można brać udział także człowiek niewierzący. W swoich argumentach musi zatem teologia fundamentalna uwzględniać każdorazowych adresatów z ich trudnościami i zarzutami. Odpowiada to zaleceniu z 1. Listu św. Piotra 3, 5: „Bądźcie zawsze gotowi do obrony wobec każdego, kto domaga się od was uzasadnienia tej nadziei, która w was jest”.

W większości zachodnioeuropejskich krajów wyzwanie i wraz z nim adresat teologiczno-fundamentalnego uzasadnienia wiary ma dzisiaj całkiem inny charakter niż wówczas, kiedy została opracowana klasyczna forma współczesnej „demonstratio christiana”. Niemiecka studentka sformułowała trafnie i krótko, z czym w tych krajach dzisiaj chrześcijaństwo ma do czynienia: „Przyjrzyjcie mi się: ja w nic nie wierzę, mnie niczego nie brakuje”. Pozostajemy w obliczu faktu, że wielu ludzi nie przypisuje już więcej ża d n e go zn a cze ni a orędziu chrześcijańskiego Objawienia. Istnieje rozpowszechnione podejrzenie, które jest dzisiaj wyzwaniem, że chrześcijańskie orędzie pozostaje dla ludzi bez znaczenia. Wobec takiego adresata klasyczna argumentacja szkolnej apologetyki staje się bezsilna.

Adresatem klasycznej współczesnej a pologe tyki, do którego zwracało się także Vaticanum $\mathrm{I}^{2}$, był de iz m $\mathrm{m}^{3}$. Ten - jak wiadomo - akceptował

\footnotetext{
${ }^{1}$ Por. M. Se ckle r, Fundamentaltheologie: Aufgaben und Aufbau, Begriff und Namen, [w:] Handbuch der Fundamentaltheologie, hrsg. von W. K e r n, H. J. P ot t m e y e r, M. S e ckle r, Bd. 4, Freiburg 1988, s. $451-514$.

${ }^{2}$ Por. H. J. Pot t m e y e r, Der Glaube vor dem Anspruch der Wissenschaft. Die Konstitution über den katholischen Glauben „Dei Filius” des 1. Vatikanischen Konzils und die unveröffentlichten theologischen Voten der vorbereitenden Kommission, Freiburg 1968.

${ }^{3}$ Por. H. J. W a lgr a v e, Das Große Mißverständnis der Apologetik, „Internationale Katholische Zeitschrift” 7 : 1978 s. 295 - 305; F. J. N i e m a n n, Jesus ald Glaubensgrund in der Fundamentaltheologie der Neuzeit, Innsbruck 1983; G. He in z, Divinam christianae religionis originem
} 
metafizyczną ideę Boga, przynajmniej jako uboczny warunek — pomyślanej zresztą jako zamkniętej — przyczynowości stworzonego świata. Jednakże deizm zwalczał fakt chrześcijańskiego Objawienia (factum revelationis). Aby się mu przeciwstawić szkolna apologetyka rozwinęła dwustopniowy dowód wiarygodności. Najpierw była wykazywana możli w o ść nadprzyrodzonego Objawienia za pomocą metafizycznych argumentów (praeambula fidei). Następnie był formułowany dowód fa kt u Objawienia. Robiono to posługując się znakami wiarygodności (signa credibilitatis), które od zewnątrz zestawione z Objawieniem mogłyby zostać także przez niewierzących zaakceptowane; dlatego nazywano je znakami zewnętrznymi (signa externa). Za takie były uważane przede wszystkim cuda Jezusa i Apostołów, które jako fakty przeciw względnie obok natury (facta contra resp. praeter naturam) powinny udowodnić nadprzyrodzoną ingerencję Boga w naturalny związek przyczynowy.

Wartość dowodowa tego tzw. dowodu z cudów jest kwestionowana dzisiaj $\mathrm{z}$ wielu powodów ${ }^{4}$. Oczywiście należy zauważyć, że nie chodzi tutaj o kwestionowanie cudów Jezusa i Apostołów. Raczej wątpi się w ścisłość dowodu z cudów. Z filoz oficzn e go punktu widzenia kwestionuje się, żeby cuda mogły być rozumiane jako fakty przeciw względnie obok natury i żeby Bóg mógł zostać uznany naukowo za ich właściwego sprawcę. To bowiem zakładałoby, że (1) wszystkie procesy naturalne przebiegają będąc całkowicie zdeterminowane i (2) że dysponujemy pełną znajomością wszystkich sił działających w naturze. To jednak nie ma miejsca. $Z$ t e olog i c z n e go punktu widzenia kwestionuje się, że fakt i treść Objawienia dadzą się ściśle rozgraniczyć i że tylko fakt Objawienia może zostać rozumowo stwierdzony. Tym samym zostaje poddany krytyce ekstrynsecyzm klasycznego dowodu $\mathrm{z}$ cudów. Z h is to ry czn e go punktu widzenia kwestionaje się tezę, że tylko Jezus i Apostołowie mogli działać cuda, i że Biblia przedstawia te cuda jako fakty przeciw względnie obok natury. Wychodząc poza tę podstawową krytykę argumentów z cudów stwierdźmy pragmatycznie, że dowód $\mathrm{z}$ cudów na dzisiejszego adresata prawie w ogóle nie oddziałuje. Fakt, że Bóg przemawiał, nie robi bowiem na nim wrażenia, ponieważ pojęcie Boga nie ma dlań większego znaczenia.

\section{NOWE ZADANIE:TRESCIOWE UZASADNIENIE WIARYGODNOŚCI}

Wobec podejrzenia, że chrześcijańskie orędzie nie ma znaczenia dla ludzi i dzisiejszego społeczeństwa, pozostaje zadanie skonstruowania apologii Logosu chrześcijańskiej nadziei (por. 1 P 3, 15). Otóż mniej fakt Objawienia, któ-

probare. Untersuchung zur Entstehung des fundamentaltheologischen Offenbarungstraktates der katholischen Schultheologie, Mainz 1984.

${ }^{4}$ Por. B. W e is s m a h r, O. Kn och, Natürliche Phänomene und Wunder, [w:] Christlicher Glaube in moderner Gesellschaft, Bd. 4, Freiburg 1982, s. 121 - 148. 
którego dowód zachowuje nadal swoją ważność, lecz sama treść chrześcijańskiego orędzia nadziei staje się rozstrzygającym argumentem, czy podstawą wiarygodności. Należy wykazać, że właśnie to orędzie bezwzględnie nas dotyczy. Jeżeli klasyczna apologetyka bazowała przede wszystkim na kryteriach i argumentach zewnętrznych (criteria et argumenta ex ter $n a$ ), to treściowy dowód wiarygodności opiera się na kryteriach i argumentach wewnętrznych (criteria et argumenta inter $n a$ ).

Nie tylko apologeci i Ojcowie Kościoła we wczesnym Kościele, lecz także współczesna apologetyka szkolna znała kryteria i argumenty wewnętrzne wiarygodności. Jednakże apologetyka szkolna nie przyznawała im większej wartości dowodowej w odniesieniu do swoich adresatów. Ponadto obrona przed racjonalizmem zmuszała ją do bardzo mocnego akcentowania charakteru treści wiary jako tajemnicy w ścisłym znaczeniu tego słowa (mysteria stricte dicta), tak że również $\mathrm{z}$ tego powodu ociągała się przed przyznawaniem większego znaczenia argumentacji wewnętrznej (argumentatio interna). Stąd w niewielkim tylko stopniu rozwinęła ona postępowanie dowodowe w oparciu o treściowe uzasadnienie wiarygodności.

W kontakcie $\mathrm{z}$ dzisiejszym adresatem ważne jest argumentatywne wykazanie siły prawdy i sensu tr eści tego co Jezus przepowiadał i czym żył: K róle stwa Boże go jako uniwersalnej dla wszystkich ludzi ważnej prawdy i jako zbawienia dla ludzi i ludzkiej społeczności oraz przyszłości. Wobec rozumu, który także działa w ożywionej nadzieją historii ludzkości, można uzasadnić, że w orędziu Jezusa idzie o człowieczeństwo człowieka i bardziej ludzkí świat, i że jest czymś rozsądnym zdać się na to orędzie. W ten sposób treść objawionego orędzia w swoim centrum, mianowicie w orędziu o Królestwie Bożym i praxis Jezusowego Królestwa Bożego, stanowi właściwą pod st a w ę w i a r y go d ności chrześcijaństwa, rozstrzygający argument wiarygodności ${ }^{5}$.

Czym są wszakże przy tym uzasadnieniu znaki wi a rygodności (signa credibilitatis), które mogłyby zostać przyjęte przez wszystkich, także przez niewierzących. W miejsce odosobnionych cudownych znaków zjawiają się św i a d ko w w i Królestwa Bożego jako znaki wiarygodności (signa credibilitatis), u których wszyscy mogą na serio dostrzec ważność Królestwa Bożego.

Podstawowym prawem Bożym ekonomiki zbawczej jest to, że Bóg poprzez ludzi pośredniczy w Objawieniu i Zbawieniu. Poczynając od Abrahama, poprzez Mojżesza i proroków, u szczytu z Jezusem, Maryją i Apostołami, aż do tych, którzy dzisiaj naśladują Jezusa przyjmuje Bóg ludzi do swojej służby. Królestwo Boże w nich znajduje historyczny kształt i działanie, poprzez świadków Królestwa Bożego można rozpoznać, czym to Królestwo Boże jest i co oznacza. Jezus Chrystus jest świadkiem Królestwa Bożego i znakiem

${ }^{5}$ Por. H. J. Pot t me y e r, Zeichen und Kriterien der Glaubwürdigkeit des Christentums, [w:] Handbuch der Fundamentaltheologie..., Bd. 4, Freiburg 1988, s. 373 - 413. 
wiarygodności orędzia o Królestwie Bożym. Znakiem i świadkiem jest Jezus Chrystus dzięki swemu przepowiadaniu i swojej praxis, łącznie z cudami dzięki swemu cierpieniu i swej śmierci oraz dzięki swemu zmartwychwstaniu ${ }^{6}$. Wobec uprzednio wyizolowanego akcentowania cudów Jezusa należy stwierdzić, że ludzie wówczas byli bardziej poruszeni przez Jego orędzie, Jego praxis ucztowania z celnikami i grzesznikami oraz przez Jego przebaczanie grzechów, aniżeli przez Jego cuda. Bardzo dobrze zrozumieli to Żydzi: cuda działali także inni, ten wszakże, który działał i zarazem przebaczał grzechy, mógł być tym, przez którego Bóg przemawiał, albo też największym bluźniercą Boga, który działal mocą szatana.

Znakami wiarygodności są także inni świadkowie, których poprzez wieki znalazło Królestwo Boże, zwłaszcza ś wi ię ci. Jednakże świadectwo Jezusa nie może być przez nic i nikogo zastąpione. Pozostali świadkowie są bowiem znakami Królestwa Bożego tylko gdy naśladują Jezusa, kiedy czynią te same dzieła i tak jak je Jezus czynił. Znakiem wiarygodności jest przede wszystkim Ko ści ó ł, który jest ciałem Chrystusa i zarazem wspólnotą świadków Chrystusa, ludem Bożym, i sakramentem Jego Królestwa ${ }^{7}$.

Ze zmianą paradygmatu od cudu do świadka jako znaku wiarygodności wchodzimy w perspektywę II Soboru Watykańskiego. Dla soboru Jezus Chrystus jest świadkiem i znakiem królestwa Bożego (por. KK 5). Swiadek jako znak, który sprawia wiarygodność, jest myślą przewodnią soborowych tekstów (por. KK 31. 38. 40. 42; DM 21; DA 8). W porównaniu z Vaticanum I zostają na Vaticanum II cuda, jak to J. Ratzinger w swoim komentarzu wywodzi, „przesunięte znacząco na skromniejsze miejsce"8. Najważniejszym znakiem wiarygodności jest dla Soboru miłość zarówno ku Bogu jak i bliźnim (por. KK 42; DA 8). „Najwyższym znakiem miłości” jest męczeństwo (KK 42).

\section{DOWODOWE POSTĘPOWANIE NA TREŚCIOWE UZASADNIANIE WIARYGODNOŚCI}

Apologetyka szkolna na uzasadnienie faktu Objawienia wypracowała calkiem koherentne postępowanie dowodowe, a mianowicie dwustopniowy oparty na cudach dowód wiarygodności. Jeżeli my teraz nie podzielamy więcej tego dowodu założeń i w jego miejsce chcemy udowodnić wiarygodność orędzia o Królestwie Bożym powołując się na świadków Królestwa Bożego, to powsta-

${ }^{6}$ Por. H. Merkle in, Jesus - Künder des Reiches Gottes, [w:] Handbuch der Fundamentaltheologie..., Bd. 2, Freiburg 1985, s. 145 - 174; J. K r e m e r, Die Auferstehung Jesu Christi, tamże, s. 175 - 196; W. Ke r n, Das Kreuz Jesu als Offenbarung Gottes, tamże, s. 197 - 222; E. B i s e r, Jesus Christus - Anspruch und Ausweis, tamże, s. 223 - 240.

${ }_{7}$ Por. H. J. Pot me ye r, Die Frage nach der wahren Kirche, [w:] Handbuch der Fundamentaltheologie..., Bd. 3 Freiburg 1986, s. $212-241$.

${ }^{8}$ Lexikon für Theologie und Kirche, E 2 s. 513. 
je pytanie o odpowiednie w tym względzie postępowanie dowodowe.

W współczesnej fundamentalnej teologii możemy stwierdzić następujące tendencje: (1) Często usiłuje się dalej kontynuować tradycyjny dowód z cudów na zmodyfikowany sposób. Przy tym zastępuje się wąskie neoscholastyczne pojęcie cudu przez poszerzone pojęcie cudu św. Autustyna; (2) Na przeciwko tego znajduje się tendencja odrzucająca możliwość racjonalnego uzasadnienia powszechnego roszczenia wiary do prawdy. Widać tu egzystancjalne i personalistyczne wpływy. Wiara jest tylko subiektywnym przekonaniem, decyzją, ślepym skokiem. Prawdę wiary uznaje się tylko fideistycznie wiarą; jej ważność nie daje się w żaden sposób racjonalnie uzasadnić; (3). Pomiędzy tymi stanowiskami mieszczą się różne usiłowania, by prawdę wiary uzasadnić w oparciu o doświadczenie i praxis. Istnieje wszakże tutaj niebezpieczeństwo, że będzie się roszczenie wiary do prawdy tylko stwierdzać, ale nie będzie się na prawdę wiary żadnych argumentów przytaczać. To niebezpieczeństwo daje się zauważyć także w narratywnej teologii. Doświadczenie i praxis, poza tym kogo dotyczą, nie są same przez się ewidentne. Ich powszechne roszczenie do ważności musi zostać potwierdzone odpowiednimi argumentami.

Jeżeli zatem przeciwstawiając się fideistycznemu stanowisku chcemy utrzymywać, że można udowodnić prawdę chrześcijaństwa i jeżeli w obliczu doświadczeniowo-praktystycznego stanowiska chcemy na jego prawdę dostarczyć argumentów, to musi się postawić pytanie o postępowanie dowodowe. $\mathrm{Z}$ niekognitywnymi względnie na doświadczenie zorientowanymi stanowiskami 2 i 3 - przeciwstawiając się neoscholastycznemu i zmodyfikowanemu dowodowi z cudów - jesteśmy zdania, że to uzasadnienie nie występuje jako zmuszający dowód w formie jakiegoś dedukcyjnego czy indukcyjnego postępowania. Bóg bowiem nie pozwala się wymuszająco udowodnić jako praprzyczyna ściśle określonych cudownych fenomenów.

Odpowiednim wydaje się sformułowanie kompleksowego dowodu na treściowe uzasadnienie wiarygodności ${ }^{9}$. W konfrontacji z innymi ujęciami rzeczywistości powinno się wykazać, że chrześcijańskie orędzie jest koherentne i przedstawia właściwe tłumaczenie rzeczywistości. To wystarcza dla wykazania jego.wiarygodności. Kompleksowe uzasadnienie dla religijnych twierdzeń zostało zaproponowane przez Basila Mitschella, emerytowanego filozofa religii w Oksfordzie. Według niego kompleksowe uzasadnienie powinno spełniać cztery warunki, a mianowicie jego poszczególne argumenty powinny się: (1) wzajemnie popierać i nie mogą (2) być fałszywe; kompleksowe uzasadnienie powinno (3) wykazywać wewnętrzną koherencję i (4) w zasadzie bez uprzedniego założenia wiary być zrozumiałe. To postępowanie dowodowe jest stoso-

${ }^{9}$ Por. J. Me yer zu Schlochtern, Glaube-Sprache-Erfahrung. Zur Begründungsfähigkeit der religiösen Überzeugung, Frankfurt 1978; H. J. P ot t m e y e r, Zeichen und Kriterien..., s. $394-400$. 
wne np. w literaturoznawstwie, gdzie również nie ma możliwości wymuszającego postępowania dowodowego.

Chrześcijańska wiara może dalej jako racjonalna zostać wystarczająco uzasadniona, albo być uznana za wiarygodną, jeżeli się w przeciwstawieniu do konkurencyjnych ujęć, np. względem ateizmu, potwierdzi jako bardziej właściwe rozumienie rzeczywistości.

\section{DOWODOWA FUNKCJA ZNAKÓW WIARYGODNOŚCI}

Jeżeli zadanie to chcemy teraz konkretnie w odniesieniu do orędzia Jezusa o Królestwie Bożym wziąć pod rozwagę, to wcześniej powstaje pytanie, jaką rolę odgrywają w tym postępowaniu dowodowym znaki wi a rygodności, św i a d k ow i e Królestwa Bożego. Spełniają oni dowodową funkcję i jakiego jest ona rodzaju?

Już powiedzieliśmy, że Królestwo Boże znajduje historyczny wyraz w swoich świadkach. Przez to stają się oni znakami królestwa Bożego, które wskazują na COŚ większego niż one same są. Świadek ułatwia dostrzeżenie rzeczywistości Królestwa Bożego. Znak posiada siłę ukazywania i otwierania, jego transparencja spełnia dowodową rolę. Im więcej świadek jest transparentn y na Królestwo Boże, tym więcej ukazuje się w jego wyznaniu i jego praxis rzeczywistość Królestwa Bożego i jego wiarygodność.

Tak właśnie Jezus był całkowicie odzwierciedleniem Ojca. „Kto mnie zobaczył, zobaczył.także i Ojca" (J 14, 9). Z kolei Paweł stał się odzwierciedleniem Chrystusa. „Teraz zaś nie ja żyję, lecz żyje we mnie Chrystus” (Ga 2, 20). I doznawal on bólów rodzenia „aż Chrystus w was się ukształtuje” $(\mathrm{Ga} \mathrm{4,19).}$ Stąd właśnie dowodowa funkcja świadków jest tylko pośrednia. Swiadkowie sami przez się nie stanowią Królestwa Bożego, lecz tylko pośredniczą jego rzeczywistość i jego wiarygodność, kiedy dają się owładnąć Królestwu Bożemu i zgodnie z nim kształtują swoje życie. Jeżeli rzeczywistość, którą się poświadcza, sama ze siebie nie jest wiarygodna, nie może być także wiarygodne świadectwo. Dlatego nie wystarczy, że teologia fundamentalna - jak to dzisiaj niekiedy się dzieje - wskazywać będzie tylko na humanitarną i heroiczną praxis chrześcijan. Samo to bowiem nie uzasadnia jeszcze wiarygodności chrześcijaństwa. Ofiara życia chrześcijańskiego męczennika wzięta jako taka nie udowadnia wiarygodności chrześcijaństwa. Umrzeć bowiem można także za sprawę, która takiej ofiary nie jest godna. Tylko wtedy męczeństwo staje się znakiem sprawy, która tego poświęcenia jest warta, staje się ono znakiem wiarygodnej rzeczywistości. Tylko u zas a $\mathrm{niaj}$ ą ca praxis jest znakiem wiarygodności. Dlatego teologia fundamentalna musi posunąć się do tre ści o w e go d ow odu wiarygodności. Tak więc Królestwo Boże względnie treści orędzia o Królestwie Bożym są właściwym i jedynym motywem wiarygodności chrześ- 
cijaństwa, które wszakże poprzez świadków Królestwa Bożego staje się żywo ukazaną rzeczywistością historyczną. Dlatego aby niewierzącym pośredniczyć wiarygodność chrześcijaństwa nie wystarczy wskazać na tę czy inną praxis. Potrzebna jest argumentacja.

Istnieje dzisiaj tendencja przyznawania praxis większej siły dowodowej niż argumentacji. Niewątpliwie jest $\mathrm{w}$ tym coś słusznego; praxis wywiera wpływ przez bezpośrednie doświadczenie, jeżeli ono sprawia dobro. Niektórzy mówią: Matka Teresa czyni przez swoją działalność więcej dla wiarygodności chrześcijaństwa niż wszyscy profesorowie fundamentalnej teologii z ich argumentami. Jednakże, ażeby być przekonywającą, także praxis Matki Teresy domaga się pewnego założenia. Zakłada mianowicie, że czymś dobrym jest umarłych grzebać, chorymi się opiekować i głodujących żywić, i to do tego stopnia, że warto złożyć ofiarę własnego życia. Wszakże praxis może się mnie wydać bezwarunkowo dobrą tylko wtedy, jeżeli jestem przekonany o bezwarunkowej wartości i bezwarunkowej godności każdego człowieka. To nasze przekonanie znajduje swoje uzasadnienie w chrześcijańskim orędziu i faktycznie właśnie to orędzie daje motywacyjną podstawę dla praxis Matki Teresy. Jej praxis tylko dlatego może przekonywać, ponieważ samo orędzie chrześcijańskie jest przekonywające.

Tylko jako uzasadniona i w swoich podstawach zrozumiała praxis życia Matki Teresy służy wiarygodności chrześcijaństwa. A dalej: wiarygodność praxis jest uwarunkowana od wiarygodności orędzia, który tę praxis uzasadnia. Chrześcijańskie orędzie musi zatem posiadać dla siebie dobre podsta w y podstawy, które w dialogu z niewierzącymi mogą służyć także jako argumenty jej wiarygodności. Stąd chrześcijańska praxis nie może sama, bez argumentacji, świadczyć przekonywująco o wiarygodności chrześcijaństwa.

I odwrotnie, argumentacja teologii fundamentalnej za wiarygodnością chrześcijańskiego orędzia musi mieć także możność odwołania się do chrześcijańskiej praxis. Orędzie chrześcijańskie przepowiada bowiem, że Królestwo Boże już zostało zainaugurowane i przynosi owoc w dobrych czynach ludu Bożego. Bez odpowiedniej chrześcijańskiej praxis pozostawałoby chrześcijańskie orędzie właściwie niewiarygodne. W ten sposób zarówno praxis jak i argumentacja mają własny wkład w uzasadnienie wiarygodności chrześcijaństwa; powinno się je od siebie odróżnić, ale nie wolno ich oddzielać.

\section{ORĘDZIE O KROLESTWIE BOŻYM JAKO PODSTAWA WIARYGODNOSCI}

Pod koniec należy przytoczyć kilka argumentów, które mogą służyć kompleksowemu uzasadnieniu wiarygodności orędzia o Królestwie Bożym. Bardziej wyczerpująco są te argumenty rozwinięte w tomie IV Podręcznika teolo- 
gii fundamentalnej. Podręcznik jako całość w swoich czterech tomach stanowi próbę kompleksowego zespołu dowodowego.

Jeżeli chcielibyśmy streścić w jednym zdaniu orędzie o Królestwie Bożym, to brzmiałoby ono następująco: Królestwo Boże jest urzeczywistnieniem zbawienia ludzi we wspólnocie z Bogiem. Jezus, „Człowiek dla innych” — jak Go D. Bonhoeffer określił — jest zn a ki e m i św i a d k i e m życzliwości Bożej dla ludzi. W proegzystencji Jezusa staje się widzialne: „Ukazała się dobroć i miłość Zbawiciela, naszego Boga do ludzi" (Tyt. 3, 4). Jakiego rodzaju jest człowieczeństwo ludzi, którego domaga się i zarazem ofiarowuje Królestwo Boże, pokazuje Jezus w przypowieściach, w błogosławieństwach Kazania na Górze i w swoim praktycznym postępowaniu z ludźmi. On przełamuje wszystkie bariery, jakie ludzie wznieśli sobie na przeciwko siebie. Dlatego stawał On zawsze po stronie wydziedziczonych i socjalnie pogardzanych. To właśnie ubodzy, głodujący i płaczący są przez Niego chwaleni jako błogosławieni (por. Łk $6,20 \mathrm{~b}-21)$. Eschatologiczna rewolucja, która oznacza Królestwo Boże, przezwycięża nawet bariery wrogeści: wróg staje się bliźnim, który nie zostaje wyłączony z miłości (por. Mt 5, 43-47). Mury, które wznosi grzech, zostają zburzone przebaczeniem otwierającym nowy początek. W orędziu o Królestwie Bożym i praxis Jezusa ukazują się zarysy świata, w którym panuje braterstwo, otwierające przyszłość wszystkim ludziom.

Do orędzia o Królestwie Bożym należy także to, że tylk o w takim Królestwie, które sam Bóg zakłada, i w którym Jego wola się spełnia, może zostać zrealizowane człowieczeństwo człowieka i bardziej ludzki świat. Jeżeli jeszcze tyllko B ó g może uratować świat, powinno się realny stan tego świata i istniejącą w nim moc nieszczęścia bardzo poważnie wziąć pod rozwagę. Radosne orędzie bowiem jest orędziem o Królestwie Bożym i zarazem sądem nad naszą historią. Jezus sam musiał przeżyć panowanie absurdu. Krzyż był konsekwencją Jego orędzia, odpowiedzią ludzi pod panowaniem zła na to orędzie. W niezwyciężonym zaufaniu Jezusa w przyjście Królestwa i w wierność Ojca ukazuje się zarazem powłoka niezwyciężonej nadziei. Krzyż staje się znakiem zbawienia.

Krzyż jest znakiem realizmu i nadziei, które nie mają nic porównywalnego w całej historii myśli religijnej. Nigdzie bowiem potęga grzechu, nędza cierpienia i umierania nie została bardziej realnie przedstawiona i poważniej potraktowana niż tam, gdzie wierzy się, że wszechmogący Bóg w swoim Synu sam stał się ofiarą za grzechy, musiał cierpieć i umrzeć, ażeby swoje Królestwo miłości zaprowadzić. I nigdzie nadzieja nie znalazła mocniejszego fundamentu niż tam, gdzie wierzy się, że ta nadzieja w cierpieniu, umieraniu i zmartwychwstaniu Boga, który stał się człowiekiem, została potwierdzona. Tak to Krzyż staje się krytyką tych ideologii, które opowiadają się za redukcją rzeczywistości.

Tego rodzaju rozumienie rzeczywistości pozwala zbadać przydatność wszystkich innych ujęć rzeczywistości. U podstaw ideologii i ich wiary w siłę sa- 
mozbawienia człowieka we wszystkich jej formach leży zapoznanie głęboko sięgających i wszystko ogarniających korzeni zła. Realizm, który potajemnie albo otwarcie nie staje się cyniczny, niezwyciężona n a dzie ja, która rzeczywiście nie jest płytkim, nie douczonym optymizmem - połączenie obojga wydaje się nierozwiązalnym zadaniem, które wszakże nieodzownie się narzuca, jeżeli się nie chce pełne nieszczęścia stany tego świata zostawić sobie w spokoju.

Dzięki temu orędzie o Królestwie Bożym wyróżnia się zarówno swoim beziluzyjnym realizmem, który stan świata i człowieka serio takim uwzględnia, jakim jest, jak i niezachwianą nadzieją w zbawiającą przyszłość człowieka. Dlatego jest ono wszystkim innym niż pocieszaniem zaświatami; połączenie realizmu z nadzieją umożliwia raczej wkład do bardziej ludzkiego świata i społeczeństwa, które są także postulatem rozumu opowiadającego się bezwarunkowo za godnością człowieka.

Powszechne braterstwo, do którego zmierza orędzie o Królestwie Bożym obejmuje nie tylko żyjących. Zmartwychwstanie Jezus a pokazuje, że zbawiająca przyszłość jest otwarta także dla zmarłych. Zmartwychwstanie Jezusa jest znakiem, że nawet bariera śmierci została przezwyciężona, która to śmierć wydaje się być absolutną granicą realizacji sensu życia tych, którzy na tym świecie nie doznali sprawiedliwości. Pełen obietnicy znak zmartwychwstania ciała, który zapowiadająco zdarzył się dla nas w Jezusie, wychodzi naprzeciw najbardziej radykalnej nadziei sensu u ludzi o cielesno-duchowej naturze. Więcej, nawet i przerasta ją.

W obliczu upadku wszystkich ideologii i dóktryn o zbawieniu, które stawiają na samozbawczą moc człowieka — klęski, która dzisiaj na naszych oczach się dokonuje - uzyskuje orędzie o Królestwie Bożym nową szansę pośrednictwa swojej wiarygodności przez świadectwo praxis i argumentację wszystkim poszukującym ludziom. 